\title{
Innovativeness of railway transport in the context of the development of tourism in Poland
}

\author{
Maciej Kozłowski ${ }^{1}$ (D) Marek Pawełczyk ${ }^{2}$ (D) Agnieszka Piotrowska-Piątek ${ }^{2}$ (D)
}

Published online: 26 August 2019

(c) The Author(s) 2019

\begin{abstract}
The article discusses the issue of innovation activities of companies in railway transport in Poland in the context of the development of tourism. Transport infrastructure and organization, along with economic, social, ecological and political factors, are the basic stimulators for the development of tourism. In literature on the subject, this problem is rarely discussed. This article is of a review and research nature. The aim of it is to consider the condition of innovativeness of railway transport companies in Poland in the context of its role in the development of tourism in Poland. To attain the goals of this research, a critical analysis of literature on the subject and desk research have been carried out, the latter drawing on the unpublished data of Statistics Poland, referring to Polish companies from section Transportation and storage, class Passenger rail transport, interurban (according to NACE rev.2). The data derive from the three latest editions of the Community Innovation Survey (CIS). In the article, there was used data concerning: innovation activity, types of innovation, co-operation during innovative activity, importance of the source of information for innovation activity, importance of the reasons and barriers to not innovate. The data analysis reveals a rather low level of innovativeness of railway transport companies in Poland. In the authors' opinion, this state of affairs is connected with historical and political factors: the structure and failed reforms in this sector and granting development priority to other branches of transport during the structural transformation in Poland.
\end{abstract}

Keywords Tourism development · Railway transport · Public policy · Innovativeness · Community Innovation Survey $\cdot$ Poland

Maciej Kozłowski

maciej.kozlowski@uni.lodz.pl

Marek Pawełczyk

m.pawelczyk@tu.kielce.pl

Agnieszka Piotrowska-Piątek

apiotrowska@tu.kielce.pl

1 Faculty of Economics and Sociology, University of Lodz, Lodz, Poland

2 Faculty of Management and Computer Modelling, Kielce University of Technology, Kielce, Poland 


\section{Introduction: the role of innovation in modern economies}

Currently, the most significant resource conditional for the development of economy in a given country is knowledge. According to the World Bank, economy based on knowledge constitutes a system in which knowledge assets are intentionally assigned more significance than capital and work assets, and in which the amount and complexity of knowledge penetrating economic and social activities achieve a very high level (World Bank 2007). Knowledge is increasingly replacing work and capital as basic sources of social wealth. The capacity to create knowledge, and foremost in translating this into new products, services and technologies, is decisive for the market success of companies and, as a result, of the entire economy. The economy requires specific 'fuel' in the form of innovations that end up on the market in the form of new products and services. Under such circumstances, creativity, innovations and initiative constitute complementary mechanisms creating the dynamics of change and competitive force of the economy (Cieślik et al. 2011). Innovativeness is not the end in itself. It is rather an instrument to form the competitive capabilities of contemporary companies.

With reference to the theory of economics, it should be noted that new theories of economic growth are currently being developed - the so-called endogenic theories, as to better explain the processes currently taking place in the economy. In their view (unlike in the case of neoclassicist models based on the assumption that the basic factors of production are work and physical capital, and that growth is determined by exogenous technical progress), technical progress is of an endogenous character, and the key role in the process of economic growth is played by human capital (Bocian 2006). The central element of the theory of new growth is the assumption of an increasing rate of return on knowledge capital (due to the fact that knowledge is not subject to the law of decreasing returns). In neoclassical growth models, decreasing rates of returns were assumed, which was justified in the case of traditional production aspects, such as land, unqualified workforce and physical capital (Florczak 2009).

This article discusses the problem of innovativeness in railway transport companies in the context of its role in the development of tourism in Poland. The level and organization of transport infrastructure, next to economic, social, political and ecological factors, is a key factor stimulating the development of tourism.

The considerations presented in this work are based on a review of literature on the subject (traditional publications and netography), as well as desk research based on data from Eurostat, Poland Statistics (including the Data Bank of Poland, containing historical data) and the Statistical Office in Szczecin. In the latter case, the presented data comes from the survey (Sprawozdanie PNT/02u), covering companies which employ ten or more people conducting activity classified under the Polish Classification of Activities 2007 into section 46 , section $\mathrm{H}$, section $\mathrm{J}$, section $\mathrm{K}$, section $71,72,73$. The study was conducted in accordance with international methodology (which is in line with those recommended by the Oslo Manual, 2005, 3rd edition) within a wider Eurostat research program: Community Innovation Survey (CIS), which covers all European and associated countries. For the purposes of this article, data concerning railway transport companies was calculated from the unit database. In accordance with the Polish Classification of Activity 2007 (complaint with the international NACE Rev.2 classification), these companies are classified under 
section $\mathrm{H}$ (Transport and warehouse management), group $49.1^{1}$ (interurban passenger railway transport). The data was drawn from the last three editions of the study covering the years: 2012-2014, 2013-2015, 2014-2016. Data concerning expenditures on innovative activity and income from the sales of innovative products cannot be presented in the article due to the confidentiality of statistical secrets (Law of June 29th, 1995 on official statistics).

\section{Railway transport and its role in the development of tourism in Poland}

Following the classical definition by W. Hunziker and K. Krapf, tourism may be described as the totality of phenomena and relations associated with travel and the stay of visitors, excluding migrants and commuters (Hunziker and Krapf 1942). This phenomenon has many aspects:

- economic aspect (due to the role performed in the structure of economy; researchers (Czerwiński 2015) often emphasize that this is currently the fastest growing domain of global economy due to its share in the creation of workplaces ${ }^{2}$ and generating GDP),

- spatial aspect (for the needs of development of tourism, the geographical environment requires it being managed and equipped with a specified tourist and semi-tourist-oriented infrastructure),

- social aspect (due to its role in building social relations and social development),

- psychological aspect (due to its position in the structure of human needs),

- cultural aspect (as an element and factor affecting civilization and cultural transformation).

Elaborations concerning the history of tourism in Poland usually indicate the following stages (Czerwiński 2015):

- the precursory period until 1873 ,

- the period between 1874 and 1918, which is when Poland regained independence, characterized by creating ideological and organizational foundations for the development of tourism and its basis-sightseeing,

- the interwar period (1918-1939), referred to as the time of institutionalizing tourism in Poland,

- the period between 1945 and 1989, characterized by the development and domination of social tourism (associated with employee holidays refunded from the means of the workplace), within a planned economy, in which the state sector was dominant,

- the fifth period, after 1989 , characterized by the development of tourism as a social phenomenon with many faces, in the conditions of a free market economy.

\footnotetext{
1 Rail transportation of passengers using railroad rolling stock on mainline networks, spread over an extensive geographic area_- passenger transport by interurban railways - operation of sleeping cars or dining cars as an integrated operation of railway companies.

${ }^{2}$ From 2008 to 2017 total number of working (full-time and part-time) in tourism sector in UE grew by 4,707,500 persons, in Poland by 622,900 (own calculations based on Labour Force Survey; https://ec.europ a.eu/eurostat/data/database).
} 


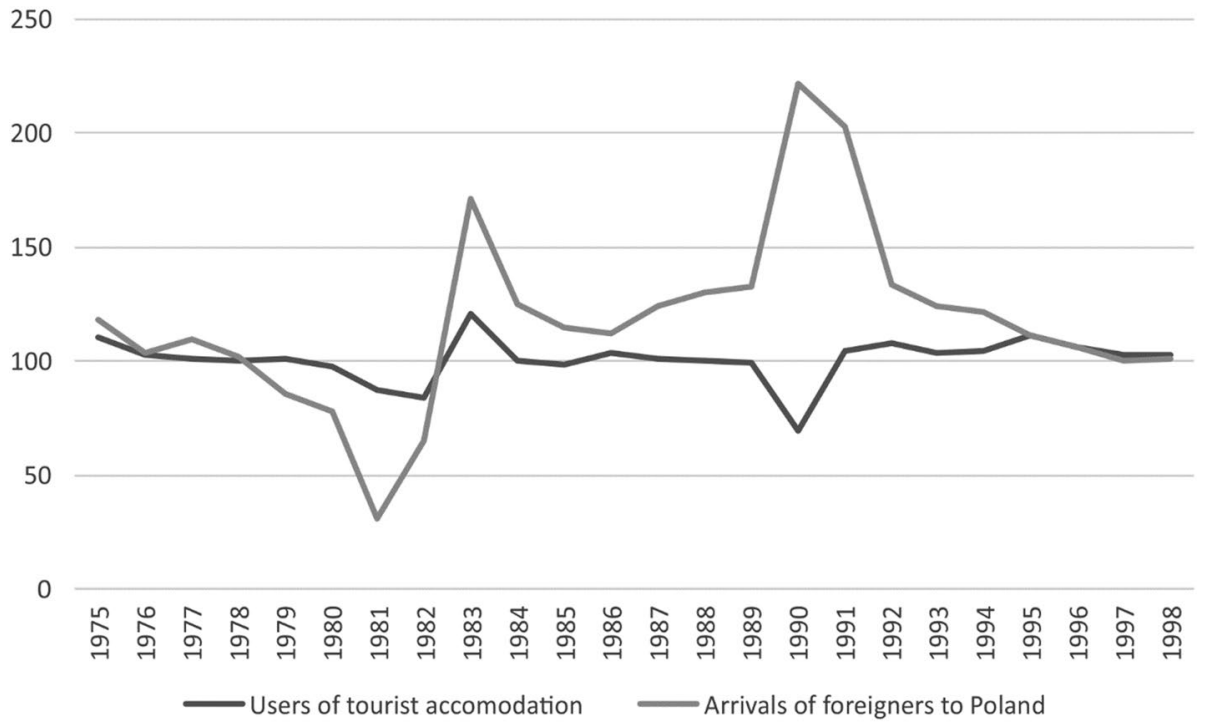

Fig. 1 The dynamics (chain dynamics index y/y) of changes of selected tourism indicators in Poland in 1975-1998. Source: own calculations and elaboration based on Data Bank of Poland; https://bdm.stat.gov. $\mathrm{pl} /$

The development of tourism is a phenomenon conditioned by political, economic, civilization and social processes, which is confirmed by an analysis of the formation of the dynamics of basic tourism indicators in a long time series (see Fig. 1). Significant events in the history of Poland, such as Martial Law (1981-1983) or the beginning of system transformation (1989), visibly affected the formation of tourist traffic (e.g. arrival of foreigners in Poland).

Apart from the above-mentioned factors, tourism is undoubtedly affected by transport infrastructure. Currently, all types of transport are involved in tourist transport: car, railway, air, maritime transport. The communication infrastructure, together with accommodation, food and accompanying infrastructures (related to the various needs of tourists), participates in the processes of tourism management.

Factors that currently make railway transport a convenient mean of transport for tourism include: speed, comfort, possibility to travel at various times of the day and season, regardless of weather, and a higher level of security as compared to other means of transport. Nowadays, less land and energy consumption and, as a consequence, the lower environmental impact of railway transport as compared to road transport are taken into consideration more often, which is very important in the context of the necessity of compliance with the principles of sustainable development in tourism management processes. It is assumed that collective transport should play a dominant role in a sustainable transport system, especially in long-distance transport (Mężyk and Zamkowska 2019). Another important feature is its larger availability for people of lower material status and motor dysfunctions than in the case of other branches of transport.

The history of railway transport in Poland began with the Warsaw-Vienna railway and the Upper Silesia railway in the 1840s. These and further initiatives developing the railway lines in Poland intensified tourism in those times, and the current condition and organization of the railway network is a result of almost 200 years of history. 


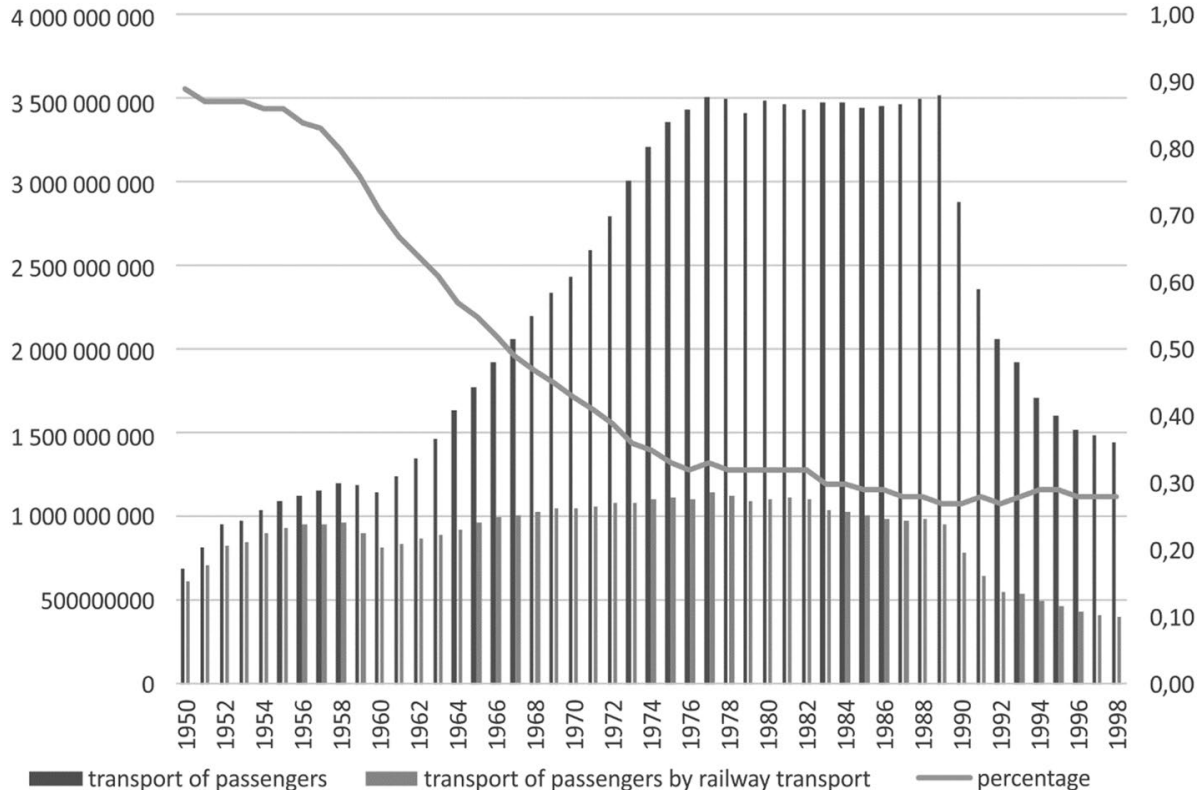

Fig. 2 Changes in the volume of passenger transport and in percentage in Poland in 1950-1998. Source: own calculations and elaboration based on Data Bank of Poland; https://bdm.stat.gov.pl/

After WWII, the situation of railway transport in Poland, and in the entire Central and Western Europe, was very different from the situation in Western European countries. The majority of countries with a planned economy, including Poland, was more transportabsorbent per 1 citizen, which included, among others, the irrationality of many market connections of companies. Railway transport in countries with centrally planned economies did not actually have to compete with other transport branches. In the case of Poland, the additional factor favoring development of railway transport at that time (in particular in the scope of transporting cargo) was the structure of industry based on the mining industry.

In the period of system transformation in Poland, i.e. from the beginning of the 1990s, we observe significant regress in the number of passenger railway transport (see Fig. 2) resulting from the state policy, which considered the development of road transport as a priority, and from social and cultural changes, which began with the transformation (including an increase in the number of people owning cars and the development of individual motorization).

In the years 1990-2010 in Poland, not enough funds were allocated for carrying out the necessary and technically justified repairs of the railway infrastructure, which led to its significant physical degradation and economic decapitalization (Engelhardt and Perenc 2016).

A result of the decrease in passenger and cargo railway transport was the liquidation of unprofitable railway lines (in 1980, the length of standard gauge railway lines amounted to $24,356 \mathrm{~km}$, while at the end of $2017-19,132 \mathrm{~km}$, including $537 \mathrm{~km}$ of wide-gauge lines). However, it should be pointed that, excessive focus on closing unprofitable rail links makes railway services less attractive, thus resulting in a further decrease in the number of passengers.

Some railway lines are currently excluded from passenger transport, and in some cases, restoration of passenger connections (mostly local) is planned after the 


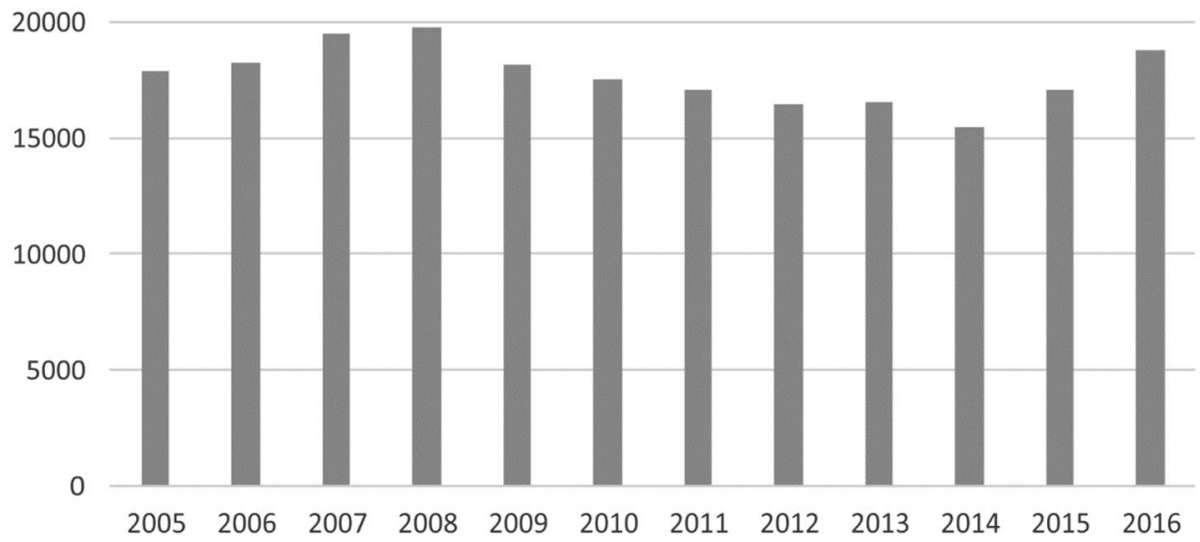

Fig. 3 Passenger railway transport in Poland in 2005-2016 (in thousands of passengers). Source: own elaboration based on Eurostat database https://ec.europa.eu/eurostat/data/database

Table 1 Changes in the number of railway transport companies in Poland and selected European countries in 2007-2016. Source: own elaboration based on Eurostat database; https://ec.europa.eu/eurostat/data/datab ase

\begin{tabular}{lrccccccccc}
\hline & 2007 & 2008 & 2009 & 2010 & 2011 & 2012 & 2013 & 2014 & 2015 & 2016 \\
\hline Finland & 1 & 1 & 2 & 2 & 2 & 2 & 2 & 3 & 2 & 3 \\
Bulgaria & 3 & 4 & 4 & 5 & 5 & 5 & 7 & 9 & 8 & 9 \\
Estonia & 11 & 9 & 9 & 9 & 9 & 7 & 7 & 8 & 8 & 8 \\
Slovakia & 9 & 12 & 15 & 16 & 14 & 14 & 17 & 16 & 16 & 16 \\
Czech Republic & 20 & 23 & 24 & 24 & 28 & 30 & 32 & 34 & 43 & 47 \\
Austria & 27 & 21 & 21 & 23 & 25 & 39 & 27 & 28 & 43 & 45 \\
Sweden & 27 & 27 & 26 & 29 & 33 & 33 & 30 & 31 & 31 & 30 \\
Switzerland & 49 & 60 & 62 & 62 & 63 & 66 & 70 & 68 & 62 & 63 \\
Poland & 39 & 43 & 47 & 48 & 57 & 58 & 69 & 69 & 72 & 75 \\
\hline
\end{tabular}

completion of undergoing repairs. Regress in the scope of the number of passengers visible from 2008 was successfully reversed, and from 2014, there has been a gradual increase in the number of passengers (see Fig. 3).

Positive changes in this scope result from modernization of the railway infrastructure, purchase of modern passenger rolling stock and repairs of railway stations and stops. In recent times the vast majority of investments in the railway infrastructure have been carried out with the support of EU funds, additionally, of the state budget, the Railway Fund and PKP PLK S.A. own resources (Ministry 2015).

In modern Europe, few countries have maintained a monopolist structure with large integrated railway companies. Since 1991, in European countries, the railway sector implements a policy (Council Directive 1991), the purpose of which is to increase interoperability and competitiveness of this sector by separating infrastructure from 
transport, which fall under separate and independent companies (Engelhardt 2014). Therefore, in the railway sector in the European Union, there are currently many national railway systems, diverse in terms of the number and scope of activity of companies (see Table 1).

Poland, the current organization of the railway transport market is the result of gradual reforms that have been introduced from 1989, in the scope of both railway transport (including the first law on railway transport of 1997) and changes in the organization of the state (including the administrative reform of 1999). As a result, the majority of standard gauge railway lines is managed by Polskie Linie Kolejowe S.A. There are also railway lines owned by other railway companies, the management of which are obliged to share the infrastructure with other railway carriers, and several companies which are the sole users of exploited railway lines (including Broad-gauge Metallurgical Line). Managers of the railway infrastructure are obliged to share the line with all interested providers of railway transport services without discrimination. In connection with the injunction to separate railway carriers from public infrastructure, resulting from legal regulations, the security of railway transport and regulation of railway traffic in Poland is supervised by the Railway Transport Office. The result of the above-described changes in the system is an increased number of providers of railway transport.

\section{Analysis of the innovativeness of railway transport companies in Poland}

A wide definition of innovativeness is adopted in the CIS study, which is compliant with the subject approach, where the subject of statistical research is the innovative activity and innovative behavior of a company as a whole. In accordance with methodology, referring to the Oslo Manual textbook (OECD, Eurostat 2005), innovative activities comprise all scientific, technological, organizational, financial and commercial activities leading to innovation or created for that purpose. Innovations also contain research and development, which are not directly associated with preparing specific innovations.

Innovation consists in implementing a new or significantly improved product or process, a new organizational method or a new marketing method in business practice, the organization of a workplace or relations with the environment. Statistical studies on innovation cover all possible levels of novelty that have already been implemented.

The company is deemed innovative if in a given time it introduces any innovations. Taxonomy based on the Oslo methodological standard includes the following types of innovations: product, process (together referred to as technological innovations) and organizational and marketing (together referred to as non-technological innovations). Product innovations consist in introducing to the market a product or service which is new or significantly improved in the scope of its features or applications, whereas it does not have to be an innovation on the market nor an innovation developed by a given company. Product innovation may result from applying new knowledge or technology, or new applications or a combination of existing knowledge and technology. Product innovations in the scope of services consist in introducing significant improvements in the manner of providing services, adding new functions or features to existing services or introducing an entirely new service. Organizational innovation, in accordance with the assumed methodology of the study, consists in implementing new organizational methods in: rules of operations adopted in the company, in the organization of a workplace or in relations with the environment 


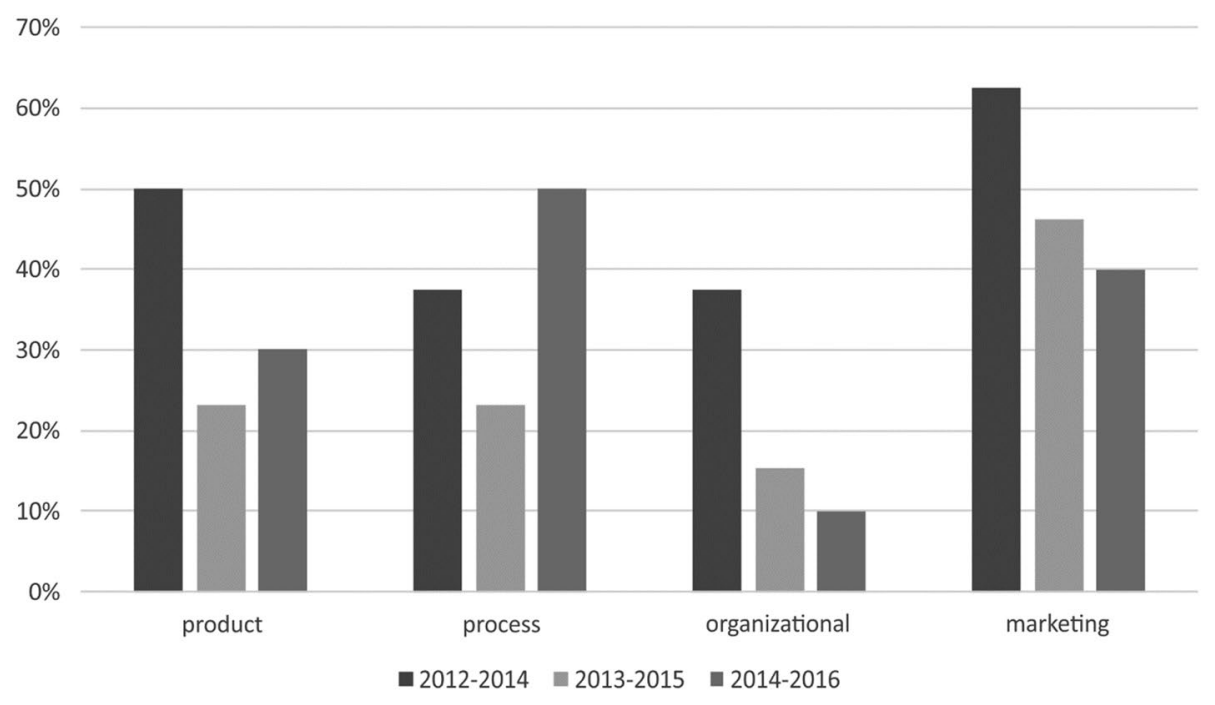

Fig. 4 Percentage of railway transport companies which in 2012-2014, 2013-2015, 2014-2016 introduced innovations (by type of innovation). Source: own elaboration based on data of Statistical Office in Szczecin

which were previously not applied in a given company. Innovation of this type results from strategic decisions made by the management, with the exception of mergers and acquisitions, even those carries out for the first time in a company. Marketing innovations consists in implementing new marketing concepts or strategies significantly different from previously applied marketing methods. It is worth adding that this type of innovation does not include seasonal, regular and other changes of a routine character in the scope of marketing strategies.

In the case of transport, the need to create and implement innovations results from the thus far insufficient efficiency of many of its technical elements and associated processes, which is manifested by unsatisfactory performance, capacity, efficiency and costs of operation. The motive behind searching for new solutions in transport is also the necessity to improve its relations with the environment by increasing spatial availability, improving the quality of services and reducing the environmental nuisance (Burnewicz 2010).

In railway transport, the basic factor stimulating the search for an implementation of new solutions is the necessity of technical integration of transport infrastructure (interoperability). Despite great progress, differences between national systems of railway transport in the scope of, for example, the wagon coupling technique or signalling system still exist. Another important factor is also the necessity to strengthen the interbank competition position, in particular as regards collective road transport.

The results of the last three editions of the study 'Report on innovations in the services sector' imply that marketing innovations (i.e. those related to market strategies and communication with recipients) were those most frequently introduced in railway transport companies, whereas organizational innovations were the least introduced (see Fig. 4).

In both cases, we deal with considerable decreasing trends (in the case of organizational innovations, the percentage of companies implementing this type of innovation amounted to 28 percentage points, and in the case of marketing innovations-23 percentage points). In the case of technological (product and process) innovations, the resulting image is unclear. 


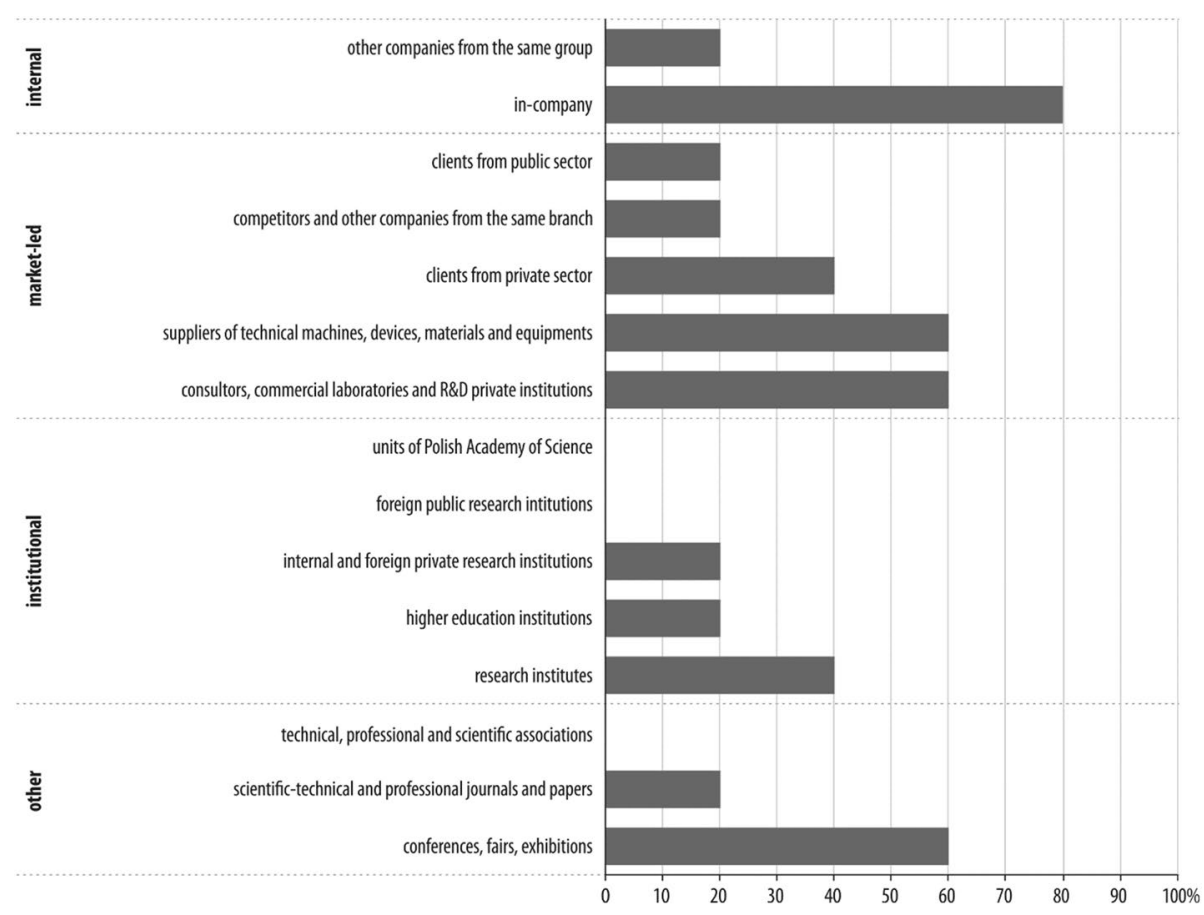

Fig. 5 Significance (high or medium level of significance) of sources of information for conducting innovative activity in percentage of railway transport companies active in the scope of innovations (2014-2016 edition of the study). Source: own elaboration based on data of Statistical Office in Szczecin

Innovativeness became the center of attention and research as early as in the 1950s. Modelling the course of innovative processes aimed at explaining, forecasting and steering the systems in which innovative processes take place was transformed over the course of time from simple linear (supply and demand) models to a complex model in which liquid company boundaries are assumed, e.g. the open model by Chesbrough (2003), as well as complex interactions with the environment, e.g. the chain-linked model by Kline and Rosenberg (1986). Due to the fact that transport systems are characterized by a high level of complexity, not only in technological but also in organizational and social terms, transport activity is of a multi-level nature and cannot be analyzed as individual activity separated from its environment (Downar 2010).

Introducing innovation to the market is associated with efforts of both individuals (inventors) and entire teams, and its distribution is both the result of its accuracy and its capacity to be absorbed by a given economy. Sources of information for conducting innovative activity may be endogenous (e.g. own $\mathrm{R}+\mathrm{D}$ units) or exogenous. Railway transport companies active in the scope of innovations find external sources to be the most significant. They less frequently seek information from: suppliers, advisory companies, commercial laboratories, private $R \& D$ institutions, as well as at fairs, conferences and exhibitions. They do not mention the scientific centers of the Polish Academy of Science, foreign public research institutions or science and technology associations as stakeholders of innovative processes (see Fig. 5). 


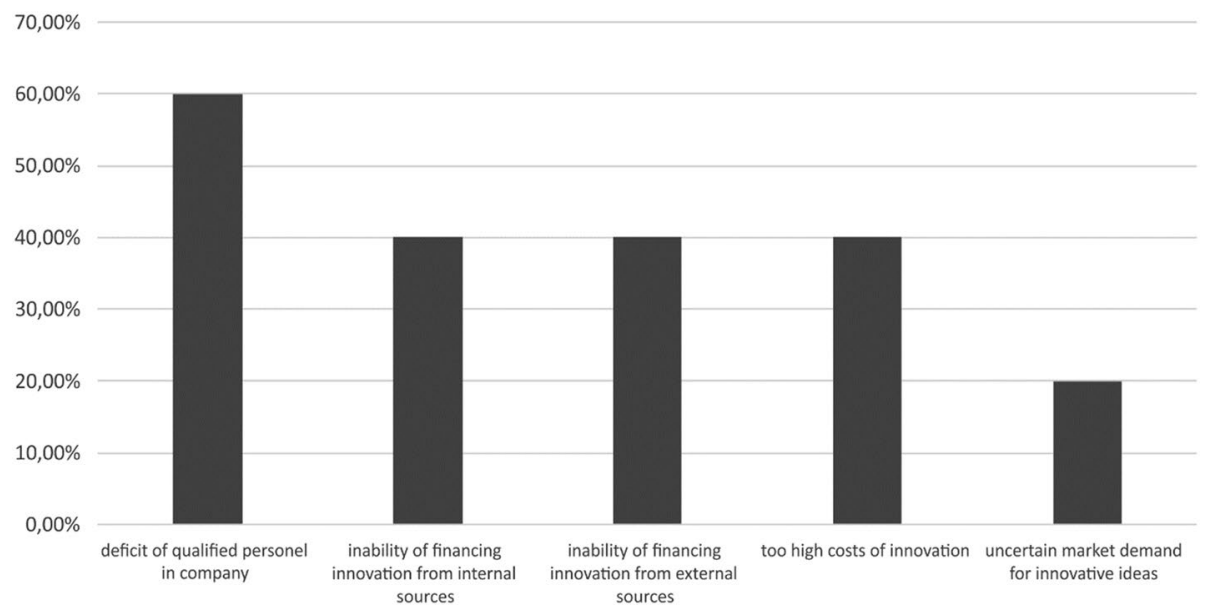

Fig. 6 Obstacles in introducing innovations in percentage of railway transport companies (2014-2016 edition of the study). Source: own elaboration based on data of Statistical Office in Szczecin

Railway transport companies which cooperated with their environment in the scope of introducing innovations deem cooperation with suppliers of materials, equipment and components, consulting companies and competition, as well as other companies from the same domain, as most beneficial. The most frequently mentioned obstacles include lack of qualified personnel and issues with financing innovations (see Fig. 6).

An important group of barriers hindering introduction of new solutions are barriers associated with the structure of the sector, which in the past (until the time of system transformation) constituted monopolization of the sector and, currently, despite deregulation, is still characterized by high susceptibility to political change, which does not favor development and innovation in the sector.

In the case of companies inactive in terms of innovations, ${ }^{3}$ the reasons for not introducing innovations included:

- lack of convincing reason for introducing innovations $(60.0 \%)$,

- too great of barriers for implementing innovations (40.0\%),

- low demand for innovations on the market (40.0\%),

- lack of need to implement innovations due to previous innovations (20.0\%),

- lack of need to implement innovations due to small competition on the market (20.0\%),

- lack of good ideas for innovations $(20.0 \%)$.

\section{Conclusions}

In the current market conditions, to maintain their competitive edge, it is essential for companies to implement new technological and market-oriented solutions. As the data presented in this paper show, the level of innovativeness of railway transport in Poland is

${ }^{3} 2014-2016$ edition of the study. 
low. This is due to the specific nature of this sector, inadequate public support as well as a number of structural reforms which have not been successful in increasing organisational efficiency or improving the business effectiveness of transportation services.

Until the 1990s, in Poland, as in other European countries, railway transportation services were monopolies, which did not trigger endogenous mechanisms that would have strengthened competitiveness of railway companies. Market plays an essential role in the condition of business players: it provides information about new technological solutions and it inspires their implementation. Polskie Koleje Państwowe had been a monopoly player for decades (from 1926 to 2000) and as such, it did not experience such marketdriven stimuli. The results of this are still visible. As the Community Innovation Survey data show, the majority of railway transport companies are of the opinion that there are no convincing reasons for implementing innovation, and every fifth railway enterprise does not introduce innovation due to lack of competition.

Admittedly, the regulation of the system of railway transportation created after the 1990s favoured demonopolisation of the railway and created formal and legal conditions for developing market and competition in this sector (Engelhardt and Perenc 2016), but it is necessary to remember that reforms undertaken by successive governments often resulted in transactional crises within the sector, hence the current excessive fragmentation of transport companies as well inadequate cooperation between them. Accordingly, they fail to make common offers of transport services or to coordinate their timetables.

The railway sector is a mature sector, of high entry barriers, both in terms of capital and legal and formal considerations. It is suggested that the competitiveness and innovativeness of railway companies can be achieved by liberalising access to the market, by eliminating vertical integration of managing infrastructure and passenger transport (the vertical integration that stifled competitive potential of an input-output system), by standardizing economic regulations and technological solutions. However, it is estimated that the differences in the railway infrastructure in EU countries are so big that it will take many years to diminish them (Rosa 2013).

A specific nature of the national system of innovation in Poland is also of great importance. The literature points to the following features of this system that hinder creating or diffusing innovation processes (Jasiński 2006):

- domination of a linear model of innovation processes (so-called technology push strategy), characteristic of developed economies in the 1970s, which has been replaced by dynamic models of interactive nature that better reflect the complexity of the processes discussed and which are conducive to achieving better results,

- little variety of forms and methods of conducting research and research collaboration as well as a low level of cooperation between science and industry,

- narrow scope of international cooperation in science and technology, reflected by Poland's very low result of balance of payments in technology.

The standard and organisation of transport services are essential in satisfying needs connected with tourism, both in terms of reaching tourism destinations and travelling within them. While analysing the history of tourism, one can see a clear dependence between progress made in transport and development of tourism (Kurek 2008), and railway transport was of key significance in this (Kowalczyk 2013). Innovative technological solutions in various branches of transport, by increasing transport capacity both in terms of numbers and distance, as well as improving comfort of passengers, have contributed immensely to intensifying tourism and enabling tourists to reach new destinations. 
Due to its features that have been presented in this paper, railway is a convenient means of transport for tourists. However, a low level of innovativeness of railway transport companies in Poland limits their development potential and makes it impossible for railway to compete for tourists with other means of transport. It is the Authors' opinion that railway companies should take more effective common actions in order to offer passengers a comprehensive tourist offer, as is the case in other sectors, e.g. in air travel. It is also worth pointing out that apart from having financial resources, competent and committed personnel, they need to have trust in the effectiveness of marketing and organisational actions, the trust which these companies seem to lack.

Open Access This article is distributed under the terms of the Creative Commons Attribution 4.0 International License (http://creativecommons.org/licenses/by/4.0/), which permits unrestricted use, distribution, and reproduction in any medium, provided you give appropriate credit to the original author(s) and the source, provide a link to the Creative Commons license, and indicate if changes were made.

\section{References}

Bocian, A.: Wzrost gospodarczy—konsekwencje dla rozwoju społecznego. In: Bocian, A. (ed.) Rozwój regionalny a rozwój społeczny, pp. 354-367. Wydawnictwo Uniwersytetu w Białymstoku, Białystok (2006)

Burnewicz, J.: Perspektywa innowacyjna transportu i logistyki. Ekonomiczne problemy usług 59, 51-63 (2010)

Chesbrough, H.: The era of open innovation. MIT Sloan Manag. Rev. 44(3), 35-41 (2003)

Cieślik, J., Guliński, J., Matusiak, K.B., Skala-Poźniak, A.: Edukacja dla przedsiębiorczości akademickiej. Wydawnictwo Polskiej Agencji Rozwoju Przedsiębiorczości, Warszawa-Poznań (2011)

Council Directive 91/440/EEC on the development of the Community's railways of 29 July 1991

Czerwiński, J.: Podstawy turystyki. CeDeWu, Warszawa (2015)

Downar, W.: Budowanie sieci relacji a innowacyjność transportu. Ekonomiczne problemy usług 59, 103116 (2010)

Engelhardt, J., Perenc, J.: Transport kolejowy. In: Wojewódzka-Król, K., Załoga, E. (eds.) Transport. Nowe wyzwania, pp. 101-176. PWN, Warszawa (2016)

Engelhardt, J.: Zasady analizy i oceny działalności gospodarczej przedsiębiorstw kolejowych. CeDeWu, Warszawa (2014)

Florczak, W.: Koncepcja wzrostu endogenicznego i gospodarki opartej na wiedzy w naukach ekonomicznych, In: Florczak, W. (ed.) Studia Prawno-Ekonomiczne, LXXX, pp. 215-239 (2009)

Hunziker, W., Krapf, K.: Grundriss der allgemeinen Fremdeverkehrlehre, Zurich (1942)

Jasiński, A.H.: Innowacje i transfer techniki w procesie transformacji. Difin, Warszawa (2006)

Kline, S., Rosenberg, N.: An overview of innovation. In: Landau, R., Rosenberg, N. (eds.) The Positive Sum Strategy: Harnessing Technology for Economic Growth, pp. 275-305. D.C. National Academy Press, Washington (1986)

Kowalczyk, A.: Relacje zachodzące między rozwojem transportu lotniczego a rozwojem turystyki. In: Pawlusiński, R. (ed.) Współczesne uwarunkowania i problemy rozwoju turystyki, 61-72. Instytut Geografii i Gospodarki Przestrzennej Uniwersytet Jagielloński, Kraków (2013)

Kurek, W. (ed.): Turystyka. Wydawnictwo Naukowe PWN, Warszawa (2008)

Law of June 29th, 1995 on official statistics (Dz. U. z 2018 r., item 997)

Mężyk, A., Zamkowska, S.: Problemy transportowe miast. Stan i kierunki rozwoju. Wydawnictwo Naukowe PWN, Warszawa (2019)

Ministry of Infrastructure and Development: The railway sector in Poland. Ministry of Infrastructure and Development, Warszawa (2015)

OECD, Eurostat: Oslo Manual. Guidelines for Collecting and Interpreting Innovation Data. OECD Publishing (2005)

Rosa, G.: Konkurencja na rynku usług transportowych. Wydawnictwo C.H. Beck, Warszawa (2013)

Sprawozdanie PNT/02u: 2012-2014, 2013-2015, 2014-2016

World Bank: Building Knowledge Economies: Advanced Strategies for Development. WBI Development Studies, Washington (2007) 


\section{Data base}

Eurostat database; https://ec.europa.eu/eurostat/data/database

Data Bank of Poland; https://bdm.stat.gov.pl/

Publisher's Note Springer Nature remains neutral with regard to jurisdictional claims in published maps and institutional affiliations. 